UDC 614:712

O. H. Butenko, Cand. Sc. (Tech.), Assoc. Prof., orcid.org/0000-0002-9814-4146,

S. Yu. Smyk, Cand. Sc. (Tech.), orcid.org/0000-0001-7020-1826,

V.A.Arsiriy, Dr. Sc. (Tech.), Prof., orcid.org/0000-0003-3617-8487,

Ye. V. Osypenko,

orcid.org/0000-0003-3240-3966
DOI: $10.29202 /$ nvngu/2019-3/12

State Higher Edukational Institution "Odesa National Polytechnic University”, Odesa, Ukraine, e-mail: alex_butenko@ ukr.net

\title{
ECOLOGICALLY SAFE SYSTEM OF CLEANING THE AIR FROM POLYDISPERSE DUST
}

Purpose. Increasing the level of environmental safety of enterprises with direct-flow aspiration systems by improving the quality of air purification from polydisperse dust in systems with standard capture equipment by isolating the flow from the environment.

Methodology. The purpose of the research was realized by developing a closed two-circuit purification system and assessing its efficiency by the mathematical modeling of the dedusting process of a particular polydisperse flow.

Findings. A scheme of a two-circuit closed system of air purification, in which the polydisperse dust is initially divided by fractional sign, is proposed. The coarse dust flow is cleaned in the main circuit and, with a minimum mass of yield, returns to the premise in the area of the collecting equipment operation. The fine dust flow is cleaned due to the repeated passage through the circulation circuit capture equipment. A method of calculation of indicators of the proposed system is developed.

Originality. The issue of increasing the level of environmental safety of small industrial enterprises and industries, where there is a need to clean air from dust, is proposed to be solved by replacing the traditional direct-flow system with a two-circuit closed one. The ecological effect is achieved by separate purification of dust particles with different fractional composition and due to the complete isolation of the system from the environment. The obtained results of mathematical modeling allowed estimating the values of the indicators of the effectiveness of the elements of the system and the nature of their changes during the work.

Practical value. The proposed system makes it possible, without significant investment into purchasing expensive high-efficiency collecting equipment, to modernize traditional direct-flow systems for cleaning dust polluted air and at the same time to achieve a significant ecological effect through almost complete elimination of emissions into the atmosphere.

Keywords: ecological safety, cleaning system, polydisperse dust, differential distribution curve, entrapment release factor

Introduction. The technological processes of many industries are accompanied by the release of a large amount of polydisperse dust in the workshops or other production facilities (production of construction or chemical materials, radioactive raw material processing enterprises, concentrating enterprises, shops of bulk material overload, and others). Sometimes the physical, chemical or radiological characteristics of the dust mass are such that it is absolutely necessary to limit their exposure to the environment as much as possible; sometimes the dust mass is a useful substance and it is economically impractical to put it into the environment. Existing direct-flow air evacuation systems on such sites are usually direct-flow, and therefore part of the dust in the amount of the mass yield is dissipated in the environment. The relative measure of this mass depends on the efficiency of the entrapment release equipment used, but the common disadvantage of such systems is the impossibility of eliminating the yield completely.

Literature review. Analysis of the current state of dust clearing shows that the most environmentally hazardous

(C) Butenko O. H., Smyk S. Yu., Arsiriy V.A., Osypenko Ye.V., 2019 area - thermal power - uses mainly direct-flow systems with one type of ash trap - battery cyclone, wet scrubber or electrofilter. Hybrid systems of ash purification for power engineering are only at the stage of development $[1,2]$. In metallurgy, more complex systems are used, which, however, still essentially remain direct-flow as during the reconstruction of the existing [3, 4], and thus during constructing of new ones $[5,6]$. In addition to the above, they often use fabric filters and even at certain stages of purification - gravity units [7,8].

Large energy, chemical and metallurgical enterprises are now investing considerable funds in environmental measures, including ash and dust cleaning. A different situation is observed with small businesses and industries, mostly located within or near settlements. These enterprises are not able to invest a lot in high-performance equipment and by this time predominantly use dry inertia traps. The effectiveness of their work does not meet the current requirements of environmental safety.

The main problem of most common dust collectors, especially inertial ones, is the low efficiency of cleaning the finely dispersed component of the dust mass. There- 
fore, it is natural that most of the modern research studies in this area are aimed at improving this particular aspect of the work of equipment. At the same time, constructive ways to increase the efficiency of collecting fine fractions of the most commonly used collectors are practically exhausted and most of the work is aimed at finding a solution to this problem by influencing the fractional composition of dust. In works [9, 10], it is suggested that the acoustic coagulation of fine dust be made before the collector, and in the work [11], the high frequency sound waves bands, that provide the best results, are defined. The main drawback of the method is the need to use additional equipment - an acoustic wave generator.

In order to solve the problem of collecting finely dispersed particles in works $[12,13]$, the authors proposed a combined cleaning system (CCS). In it, the polydisperse dust is initially divided on a fractional basis in a separating apparatus. A coarsely dispersed dust flow enters the main collector and, since the efficiency of collecting the coarse dust is high (even in dry inertial collectors), the yield to the environment is minimal. This provides an ecological effect. The flow of finely dispersed dust is cleared due to the repeated passage of the circulation circuit.

The theoretical analysis and the first experience of application showed the effectiveness of the CCS. Implementation of the scheme did not require significant investment, but provided significant improvement in gas purification due to the separate purification scheme.

Unsolved aspect of the problem. In spite of efficiency, according to its scheme, the CCS remains essentially direct-flow and does not ensure the complete isolation of the environment from pollution. Therefore, in order to solve this problem, in this article it is proposed to modernize the CCS so that it retains its main advantage - the separate purge of coarse and fine fractions - and isolates the dusty flow from the environment.

Purpose. The goal of the work is to develop an efficient and environmentally safe air cleaning system against polydisperse dust and evaluate the performance of this system.

Methods. The research was carried out by mathematical modeling of the system with the use of partial characteristics of the equipment efficiency and the differential dust mass distribution curve.

Results. The schematic diagram of a two-circuit closed cleaning system (TCCCS) is presented in Fig. 1. Collected in the collecting-return apparatus (CRA), 1 the primary air flow with a flow mass of dust $M_{1-2}$ does not come directly to the collector. After mixing with the pre-purified flow of circulation circuits in the central ejector 2 , it enters the separating apparatus 3 , which is divided into two parts on a fractional basis. The flow with fine fractions of dust $M_{3-5}$ is directed to the collector of the circulating circuit 5 , and the flow with coarse fractions of mass $M_{3-4}$ - into the main collector 4 . Since the entrapment release factor of coarse fractions is quite high, the yield of dust in the main apparatus $M_{4-1}$ is insignificant. This dust returns to the premises in the zone of work of the CRA and gets cleaned again after collecting. The flow of circulation circuit with mass of $M_{5-2}$ is mixed in the ejector 2 of the primary flow after cleaning and through the separating apparatus, it is sent for clear-

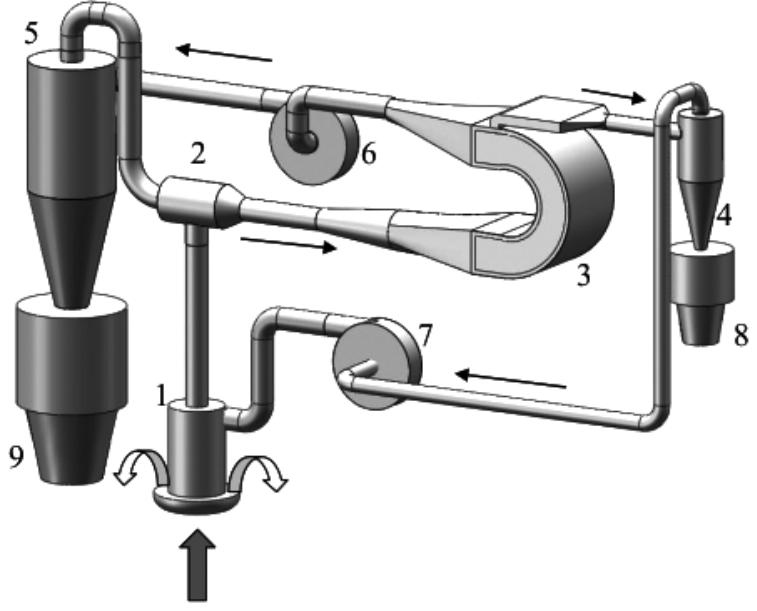

Fig. 1. Scheme of the two-circuit closed cleaning system:

1 - collecting-return apparatus; 2 - mixing machine; 3 separating apparatus; 4 - main circuit collector; 5 - circulation circuit collector; 6 - circulation circuit fan; 7-main circuit fan; 8, 9-sludge storage hopper

ing again. Thus, firstly, due to repeated passage of a dusty flow of the collector, the removal of fine fractions is ensured, and secondly, the system is closed, which excludes pollution of atmospheric air.

Depending on the physical properties and the disperse composition of the dust, the system can be assembled by various standard injection and treatment equipment. As a mixing machine, a central ejector is used, the design of which takes into account the recommendations [14].

The difference of the TCCCS from conventional aspiration systems is that the traditional covers used in such systems are not used in the TCCCS, since they are only intended for collecting polluted air and are not structurally suitable for returning it to the premises. Therefore, the CRA needed a fundamentally new solution. The task of collecting-returning is proposed to solve at the expense of the scheme, in which the pollinated gas is collected through a cylindrical pipe, and after cleaning returns to the premise on the ring channel coaxial to it (Fig. 2). The pipe connection to the appli-

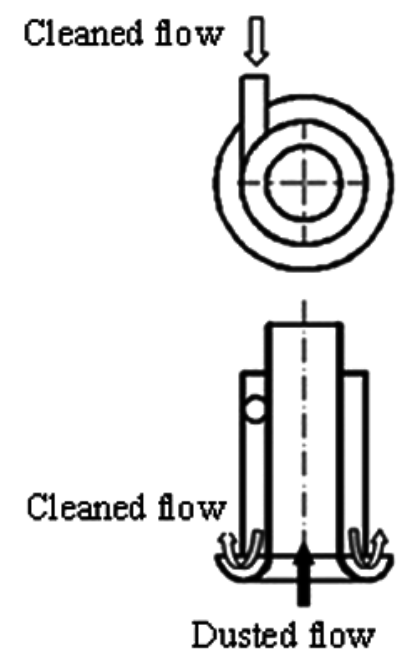

Fig. 2. Construction of the collecting-return apparatus 
ance is connected tangentially. As the results of numerical simulation in the SOLID WORKS COSMOS FLO [15] software environment have shown, such a design provides a spin of flow and a higher compactness of free jet near the collecting-return apparatus. This, in its turn, contributes to a higher percentage of secondary collecting of the mass of the main collector yield.

CRA includes the volume flow of polluted air $Q_{1-2}$, which brings a dust mass consisting of dust from the source of pollution $M_{0}$ and dust of the main collector yield $M_{4-1}$

$$
M_{1-2}=M_{0}+M_{4-1}=Q_{1-2} C_{0}+M_{4-1},
$$

where $M_{4-1}$ is the mass flow of returning dust, $\mathrm{kg} / \mathrm{s} ; C_{0}$ is dust concentration in the primary flow, $\mathrm{kg} / \mathrm{m}^{3}$.

Differential distribution curve (DDC) of the mass collected in this way (percentage) is

$$
N_{1-2}=\frac{\left(M_{0}^{i}+M_{4-1}^{i}\right) 100}{\left(M_{0}+M_{4-1}\right) 10}
$$

where $M_{0}^{i}$ is the mass of the $i^{\text {th }}$ fraction of dust; $M_{4-1}^{i}$ is the mass of the $i^{\text {th }}$ fraction of dust coming from the source of the dust (the entire range of dust particles size $\Delta(\mu \mathrm{m})$ is divided into 10 equal segments).

The mixing machine includes the mass

$$
M_{2-3}=M_{1-2}+M_{5-2} \text {, }
$$

DDC of which is

$$
N_{2-3}=\frac{\left(M_{1-2}^{i}+M_{5-2}^{i}\right) 100}{\left(M_{1-2}+M_{5-2}\right) 10} .
$$

Mass of dust of the circulation circuit collector yield is, $\mathrm{kg} / \mathrm{s}$

$$
M_{5-2}=M_{3-5}\left(1-\eta_{c}\right),
$$

where $\eta_{c}$ is the entrapment release factor of the circulation circuit apparatus.

DDC of this mass is

$$
N_{5-2}^{i}=N_{3-5}^{i}\left(1-\eta_{c}^{i}\right),
$$

where $\eta_{c}^{i}$ is the partial entrapment release factor of the circulation circuit apparatus.

The volumetric flow rate of air entering the separating apparatus is

$$
Q_{2-3}=Q_{1-2}+Q_{5-2}
$$

The main collector receives the mass

$$
M_{3-4}=M_{2-3} \eta_{s}
$$

where $\eta_{s}$ is the proportion of dust mass coming from the separating apparatus into the main collector (coefficient of separation).

Its DDC is

$$
N_{3-4}^{i}=N_{2-3}^{i} \eta_{s}^{i} \text {. }
$$

The volume flow of air entering the main collector is

$$
Q_{3-4}=Q_{2-3} q_{0},
$$

where $q_{\mathrm{o}}$ is a share of gas coming from the separating apparatus into the main collector.

The collector of the circulation circuit receives the mass

$$
M_{3-5}=M_{2-3}\left(1-\eta_{s}\right) .
$$

Its DDC is

$$
N_{3-5}^{i}=N_{2-3}^{i}\left(1-\eta_{s}^{i}\right)
$$

where $\eta_{s}^{i}$ is the partial separating factor.

Volume flow of air entering the collector of the circulation circuit

$$
Q_{3-5}=Q_{2-3}\left(1-q_{0}\right) .
$$

From the collector of the circulation circuit the following mass is obtained

$$
M_{5-2}=M_{3-5}\left(1-\eta_{c}\right) \text {. }
$$

Its $\mathrm{DDC}$ is

$$
N_{5-2}^{i}=N_{3-5}^{i}\left(1-\eta_{c}^{i}\right)
$$

The main apparatus entrapment release factor is

$$
\eta_{m}=\sum_{i=1}^{10} \frac{\eta_{m}^{i} N_{3-4}^{i} 10}{100},
$$

where $\eta_{m}^{i}$ is the partial entrapment release factor of the main apparatus.

The circulation circuit apparatus entrapment release factor is

$$
\eta_{c}=\sum_{i=1}^{10} \frac{\eta_{c}^{i} N_{3-5}^{i} 10}{100} .
$$

The mass collected in the main apparatus is

$$
M_{4}=M_{3-4} \eta_{m} .
$$

The mass collected in the apparatus of the circulation circuit is

$$
M_{5}=M_{3-5} \eta_{m} .
$$

The mass of the yield of the main collector is

$$
M_{4-1}=M_{3-4}\left(1-\eta_{m}\right) \text {. }
$$

The methodology for calculating the system's indicators can be illustrated by the example of TCCCS, developed for air purification, which is selected from the construction material shredding room, commissioned by a company specializing in dismantling old buildings. The sieve analysis of samples of collected dust allowed obtaining a differential distribution curve $N^{i}=f(\Delta)$ (curve 1 in Fig. 3). The actual dust density determined by the pycnometric method was $2.046 \mathrm{~kg} / \mathrm{m}^{3}$. The relative thickness of the selection gap of the main flow of the separating apparatus was assumed to be equal $\bar{a}=0.1$. In this case, $4.77 \%$ of the loss is retrieved to the main channel $Q_{2-3}$, and to the circulation circuit $-95.23 \%$. The volume flow of polluted air at the entrance to the system should be equal to the loss of the main channel $Q_{1-2}=Q_{4-1}$. It was adopted to be equal to $3.8 \cdot 10^{-2} \mathrm{~m}^{3} / \mathrm{s}$. 


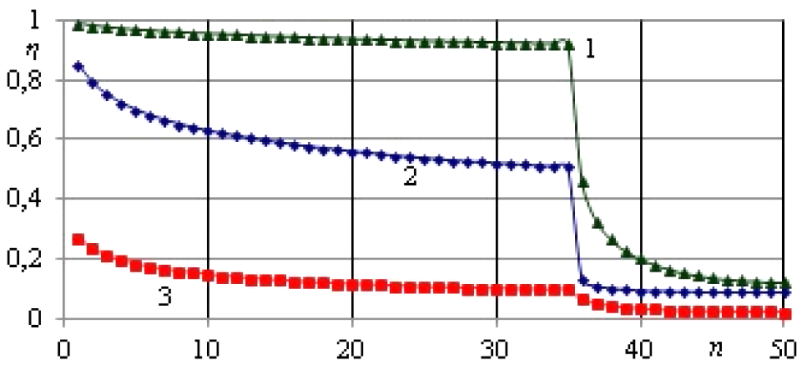

Fig. 3. Dynamics of change in values $\eta_{0}(1), \eta_{c}(2)$ and $\eta_{s}$ (3) while cleaning system operates

This condition corresponds to the flow of the circulation circuit $Q_{3-5}=0.762 \mathrm{~m}^{3} / \mathrm{s}$ and the loss of the output of the ejector into the separating apparatus $Q_{2-3}=0.8 \mathrm{~m}^{3} / \mathrm{s}$. On the basis of these data, geometric parameters of the cyclones to be manufactured were calculated (as the prototype, an element of the battery cyclone BCU type "Energovugillia" was adopted). In addition, partial entrapment release factor dependencies for partial cyclone $\eta_{c}^{i}=f(\Delta)$ and $\eta_{o}^{i}=f(\Delta)$, necessary to evaluate the system's efficiency, were calculated.

A characteristic feature of the TCCCS is that after the discontinuity of dust separation (stopping of the crushing plant), a circle of dust is required for a short period of operation - the time of a run. Therefore, the calculation of the system by the above methodology was carried out for the standard operating mode and stopping regime $\left(M_{0}=0\right)$.

Because it was impossible to accurately determine the mass flow of dust released from the crushing plant, $M_{0}$ it was conditionally adopted as equal to one and calculations were made in fractions of this magnitude. Fig. 3 shows the graphs of the changes in the efficiency of individual elements of the TCCCS, and in Fig. 4 dynamics of change of relative masses $m_{k}=M_{k} / M_{0}$ is shown. Here the first 35 cycles are the standard cleaning time, the next 25 - hours stopping regime (the cycle time is the time for which the flow makes a full circle along the circulation circuit).

The DDC of dusty masses of all system flows was also calculated. In Figs. 5-7, as an example, the distribution curves for $M_{2-3}, M_{3-5}$ and $M_{4-1}$ are shown.

Fig. 3 shows that in the mode of standard work, and in the stopping regime, two distinct periods can be dis-

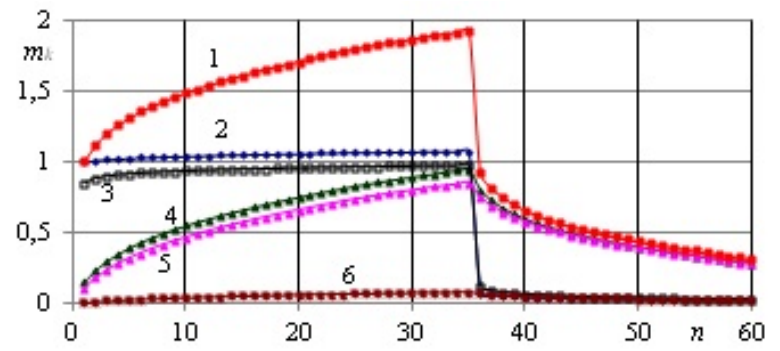

Fig. 4. Dynamics of change in relative masses:

$1-M_{2-3} / M_{0} ; 2-M_{1-2} / M_{0} ; 3-M_{3-4} / M_{0} ; 4-M_{3-5} / M_{0}$; $5-M_{5-2} / M_{0} ; 6-M_{4-1} / M_{0}$

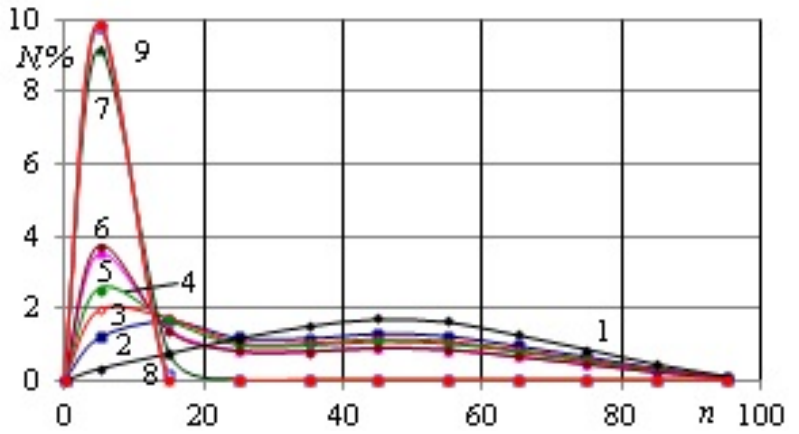

Fig. 5. Dynamics of change in DDC of dust mass $M_{2-3}$, standard work mode:

$1-n=1 ; 2-n=5 ; 3-n=10 ; 4-n=15 ; 5-n=30 ; 6-$ $n=35$; stopping regime: $7-n=40 ; 8-n=45 ; 9-n=60$

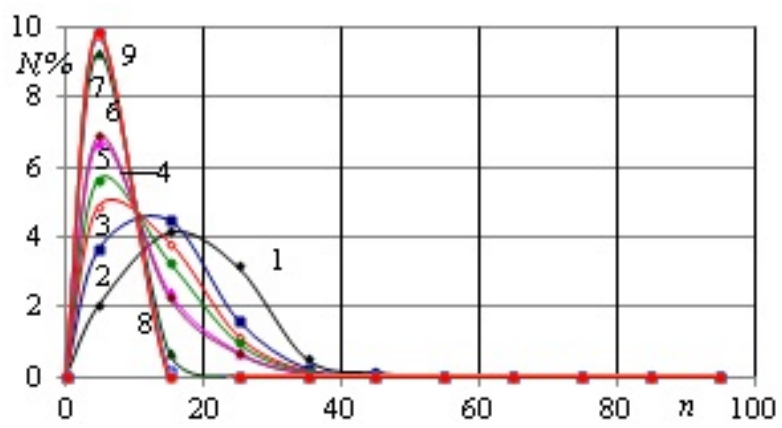

Fig. 6. Dynamics of change in dust mass DDC $M_{3-5}$, the mode of standard work:

$1-n=1 ; 2-n=5 ; 3-n=10 ; 4-n=15 ; 5-n=30 ; 6-$ $n=35$; stopping regime: $7-n=40 ; 8-n=45 ; 9-n=60$

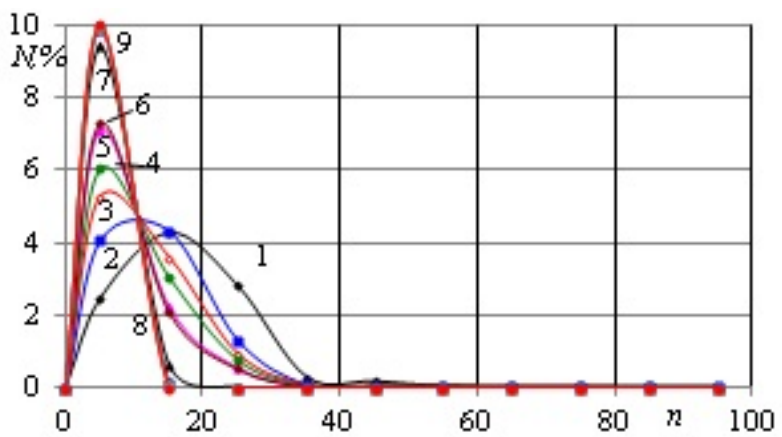

Fig. 7. Dynamics of the change in DDC of dust mass $M_{4-1}$, standard work mode:

$1-n=1 ; 2-n=5 ; 3-n=10 ; 4-n=15 ; 5-n=30 ; 6-$ $n=35$; stopping regime: $7-n=40 ; 8-n=45 ; 9-n=60$

tinguished: the period of variables and the period of their practically constant values. This is, as you can see from Figs. 5-7, due to the fact that at the beginning of both regimes, the disperse composition of the dust mass significantly changes, and over time this change becomes insignificant.

The main integral indicator of the TCCCS is the relative mass of dust, which for the entire period of work has returned from the main circuit to the premises $M_{4-1}^{\Sigma} / M_{0}=2.902$ (1.911 accounted for 35 cycles of 
standard work mode and 0.991 for 25 cycles of stopping regime). Therefore, the magnitude $M_{4-1}^{\Sigma} / M_{0}$ can be reduced to 1.911, if at the time of a stopping regime, the access to polluted air to the main channel is blocked. A relative disadvantage of such an event will be that it will lead to a certain increase in stopping time.

The calculation of the TCCCS, some of the results of which are given above, were repeated for a separating apparatus with a relative gap width of 0.2 and 0.3 under other unchanged conditions. In Table, indicators are given which allow estimating how the basic constructive parameter of a separating apparatus affects the system operation.

In Table $\eta_{c 35}, \eta_{m 35}, \eta_{s 35}$ are the coefficients of cyclone collection of the circulating and main circuit and the separation factor of 35 cycles of the TCCCS (the last cycle of the standard work mode) respectively, $M_{4-1}^{\Sigma}$ is the total relative return mass for 60 cycles, $M_{4-1}^{\Sigma 35}$ is the total relative return mass for 60 cycles, provided that the main channel is disabled at stopping regime.

As you can see, an increase in $\bar{a}$ leads to an increase in the efficiency of the circulation circuit collector and the reduction of the efficiency of the main collector and the corresponding increase in the mass of return $M_{4-1}^{\Sigma}$. This is due to the fact that the amount of dust entering the main circuit depends on $\bar{a}$. The more $\bar{a}$ is, the bigger values $\eta_{s}^{i}$ and $M_{3-4}$ are, and this increase is due to finely dispersed dust, the efficiency of collecting is low. Thus, $M_{4-1}^{\Sigma}$ increases. For a similar reason, the mass of dust moving in the circulation circuit decreases.

Conclusion. Thus, the conducted studies allowed proposing an environmentally safe system for cleaning air from polydisperse dust. The system implements the principle of separate cleaning and is closed. Its implementation does not require significant investments and fundamentally new approaches in the storage (burial) of collected dry dust sludge. The proposed methodology for calculating the system's parameters allows determining the second masses of dust and its DDC for all elements of the system in the mode of cleaning and stopping. Calculations according to this method showed that the efficiency of the main collector is $92 \%$. For dry inertial collectors, this value is uncharacteristically high. It is achieved due to the influence on the disperse composition of the dust mass.

\section{References.}

1. Miller, B. G. (2010). Advanced flue gas dedusting systems and filters for ash and particulate emissions control in power plants. In D. Roddy (Ed.), Advanced Power Plant Materials, Design and Technology, (pp. 217-243). Cambridge: Woodhead Publishing. Retrieved from

Table

Indexes of the TCCCS at different $\bar{a}$

\begin{tabular}{|c|c|c|c|c|c|}
\hline $\bar{a}$ & $M_{4-1}^{\Sigma} / M_{0}$ & $M_{4-1}^{\Sigma 35} / M_{0}$ & $\eta_{m 35}$ & $\eta_{c 35}$ & $\eta_{s 35}$ \\
\hline 0.1 & 2.90 & 1.91 & 0.92 & 0.10 & 0.51 \\
\hline 0.2 & 4.35 & 3.07 & 0.89 & 0.11 & 0.64 \\
\hline 0.3 & 4.37 & 3.23 & 0.87 & 0.14 & 0.68 \\
\hline
\end{tabular}

https://www.sciencedirect.com/science/article/pii/ B978184569515650008X.

2. Omine, M., Nagayasu, T., Ishizaka, H., Miyake, K., Orita, K., \& Kagawa, S. (2017). AQCS (Air Quality Control System) for Thermal Power Plants Capable of Responding to Wide Range of Coal Properties and Regulations. Mitsubishi Heavy Industries Technical Review, 3, 55-62.

3. Stalinskii, D.V., Mantula, V.D., Pirogov, A. Yu., Shaparenko, A. V., \& Shvets, M. N. (2016). Reconstruction of gas-purification system and ladle-furnace unit at PAO Severstal'. Stal', 2, 77-81.

4. Arisov, S. E., Rutkovskiy, O.A., \& Guk, N.S. (2016). Effective technology for gas cleaning ventilation systems sinter shop PJSC "Nikopol plant of ferroalloys". Ekologiya i promyshlennost', 2, 14-19.

5. Litvinenko, A. V. (2016). Construction of a block of gas-measuring structures with a collector system of flue gas ducts for ferroalloy furnaces in Melting Shop No. 4 of PJSC "Zaporozhye Ferroalloy Plant". Ekologiya $i$ promyshlennost', 1, 36-40.

6. Pirogov, A.Yu., Shvets, M.N., Frolov, V.S., Kuznetsova, L. N., \& Gakheladze, G.S. (2015). Effective gas removal and gas cleaning system for electric arc furnace furnaces in the foundry of PJSC "Turboatom". Ekologiya i promyshlennost', 3, 12-22.

7. Winfield, D., Cross, M., Croft, N., \& Paddison, D. (2012). Geometry optimisation of a gravity dust-catcher using computational fluid dynamics simulation. Chemical Engineering and Processing: Process Intensification, 62, 137-144.

8. Karamushko, A. V. (2018). Cleaning the gas flow from polydisperse dust in the apparatus of dynamic action. The international journal of Sustainable development, $8(1), 68-73$.

9. Ng, B. F., Xiong, J. W., \& Wan, M. P. (2017). Application of acoustic agglomeration to enhance air filtration efficiency in air-conditioning and mechanical ventilation (ACMV) systems. US National Library of Medicine. National Institut of Health, 12(6), e0178851. DOI:10.1371/ journal.pone. 0178851 .

10. Zhou, D., Luo, Z., \& Fang, M. (2015). Preliminary Experimental Study of Acoustic Agglomeration of Coalfired Fine Particles. Procedia Engineering, 102, 1261-1270. 11. Zhou, D., Luo, Z., Jiang, J., Chen, H., Lu, M., \& Fang, M. (2016). Experimental study on improving the efficiency of dust removers by using acoustic agglomeration as pretreatment. Powder Technology, 289, 52-59.

12. Butenko, A. G., \& Smyk, S. Yu. (2010). Combined air purification system. Energotekhnologii $i$ resursosberezhenie, 6, 66-69.

13. Butenko, O.H., \& Smyk, S. Yu. (2011). Hydraulic calculation of the combined air purification system. Pratsi Odes'koho politekhnichnoho universytetu, 1(35), 191-195.

14. Butenko, A. H., \& Smyk, S. Yu. (2015). Improvement of the central ejector efficiency under nonoptimal operating modes. Naukovyi Visnyk Natsionalnoho Hirnychoho Universytetu, 2(146), 57-61.

15. Aliamovskii, A.A. (2012). SolidWorks. How to solve practical problems. St. Petersburg: VHV - Peterburg. 
Retrieved from https://books.google.com.ua/books?id $=1 \mathrm{cQZuxVACn} 4 \mathrm{C} \&$ printsec $=$ frontcover $\& \mathrm{hl}=\mathrm{ru} \# \mathrm{v}=\mathrm{O}$ nepage \&q\&f=false.

\section{Екологічно безпечна система очищення повітря від полідисперсного пилу}

\author{
О. Г. Бутенко, С. Ю. Смик, В.А. Арсірій, \\ C. В. Осипенко
}

Державний вищий навчальний заклад „Одеський національний політехнічний університет“, м. Одеса, Україна, e-mail: alex_butenko@ukr.net

Мета. Підвищення рівня екологічної безпеки підприємств із прямоточними аспіраційними системами за рахунок поліпшення якості очищення повітря від полідисперсного пилу в системах зі стандартним уловлюючим обладнанням шляхом ізоляції потоку від навколишнього середовища.

Методика. Мета дослідження реалізовувалася шляхом розробки замкнутої двоконтурної системи очищення та оцінки іiі ефективності методом математичного моделювання процесу знепилювання конкретного полідисперсного потоку.

Результати. Запропонована схема двоконтурної замкнутої системи очищення повітря, в якій полідисперсний пил спочатку ділиться за фракційною ознакою. Потік із грубодисперсним пилом проходить очистку в основному контурі та з мінімальною масою виносу повертається до приміщення в зону дії збирального апарату. Потік із тонкодисперсним пилом очищається за рахунок багаторазового проходження уловлювача циркуляційного контуру. Розроблена методика розрахунку показників запропонованої системи.

Наукова новизна. Проблему підвищення рівня екологічної безпеки невеликих промислових підприємств і виробництв, де є потреба в очищенні повітря від пилу, запропоновано вирішувати шляхом заміни традиційної прямоточної системи на двоконтурну замкнуту. Екологічний ефект досягається за рахунок роздільної очистки пилових мас 3 різним фракційним складом і за рахунок повної ізоляції системи від навколишнього середовища. Отримані результати математичного моделювання дозволили оцінити величини показників ефективності елементів системи та характер їх зміни під час роботи.

Практична значимість. Запропонована система дозволяє без значних капіталовкладень на придбання дорогого високоефективного уловлюючого обладнання модернізувати традиційні прямоточні системи очищення запиленого повітря та при цьому досягти значного екологічного ефекту шляхом практично повного усунення викидів до атмосфери.

Ключові слова: екологічна безпека, система очищення, полідисперсний пил, диференційна крива розподілення, коефіцієнт уловлення

\section{Экологически безопасная система очистки воздуха от полидисперсной пыли}

\author{
А.Г.Бутенко, С. Ю. Смык, В.А.Арсирий, \\ E. В. Осипенко
}

Государственное высшее учебное заведение „Одесский национальный политехнический университет“, г. Одесca, Украина, e-mail: alex_butenko@ukr.net

Цель. Повышение уровня экологической безопасности предприятий с прямоточными аспирационными системами за счет улучшения качества очистки запылённого воздуха от полидисперсной пыли в системах со стандартным улавливающим оборудованием путем изоляции потока от окружающей среды.

Методика. Цель исследования реализовывалась путем разработки замкнутой двухконтурной системы очистки и оценки ее эффективности математическим моделированием процесса обеспыливания конкретного полидисперсного потока.

Результаты. Предложена схема двухконтурной замкнутой системы очистки воздуха, в которой полидисперсная пыль делится по фракционному признаку. Поток с грубодисперсной пылью проходит очистку в основном контуре и с минимальной массой выноса возвращается в помещение в зону действия собирающего аппарата. Поток с тонкодисперсной пылью очищается за счет многократного прохождения уловителя циркуляционного контура. Разработана методика расчета показателей предложенной системы.

Научная новизна. Проблему повышения уровня экологической безопасности небольших промышленных предприятий и производств, где есть потребность в очистке воздуха от пыли, предложено решать путем замены традиционной прямоточной системы на двухконтурной замкнутую. Экологический эффект достигается за счет раздельной очистки пылевых масс с различным фракционным составом и за счет полной изоляции системы от окружающей среды. Полученные результаты математического моделирования позволили оценить величину показателей эффективности элементов системы и характер их изменения во время работы.

Практическая значимость. Предложенная система позволяет без значительных капиталовложений на приобретение дорогого высокоэффективного улавливающего оборудования модернизировать традиционные прямоточные системы очистки запылённого воздуха и при этом достичь значительного экологического эффекта путем практически полного устранения выбросов в атмосферу.

Ключевые слова: экологическая безопасность, система очистки, полидисперсная пыль, дифференциальная кривая распределения, коэффициент улавливания

Рекомендованодо публікації докт. техн. наук А.С.Мазуренком. Дата надходження рукопису 09.02.18. 